\title{
Private Universities in Vietnam: Reflection and Proposition
}

\author{
Lu Lin Zhou \\ School of Management, Jiangsu University \\ Zhenjiang, Jiangsu, China 212013 \\ Anh Bach \\ School of Management, Jiangsu University \\ Zhenjiang, Jiangsu, China 212013 \\ Van Bach \\ Faculty of Administration, Hochiminh City University of Law, \\ Hochiminh, Vietnam 700000
}

\begin{abstract}
This paper discusses the progression of non-public universities in Vietnam through 30 years of national policy development. Since the first time that other forms of educational provision, rather than public, appeared on the scene, the private sector of Vietnam's higher education has changed intensively and contributed significantly to the overall development of the country. Nonetheless, this sector continues to lag in all aspects, including learning and teaching facilities, student enrollment, as well as academic staff. The quality of a private-university education also remains a concern. Meanwhile, the lack of favourable policies and mechanisms deters investment in private universities and affects a healthy competition mechanism between public and private institutions. Based on the analysis of private universities' achievements and challenges, three critical issues, namely admission, quality, and autonomy, are thoroughly discussed. These are the issues that currently hinder the growth of this sector. However, when appropriately dealt, they will open up new development opportunities. In these aspects, the paper proposes several suggestions for the private sector to enhance their achievements and impact in the context of Vietnam's higher education.
\end{abstract}

Keywords: higher education; non-public; private; quality; admission; autonomy.

\section{Introduction}

Enhancing the quality of human resources that facilitate the country's economic growth, education is highly valued and prioritized in Vietnamese society. In the country of more than 95 million citizens, as much as a quarter of the total 
population is estimated to be involved in formal education and training activities (General Statistics Office, 2017). Vietnamese education system follows 5-4-3 structure, i.e. five years of elementary school (grades 1-5), four years of lower secondary education (grades 6-9), followed by three years of upper secondary education (grades 10-12). As students graduate from lower or upper secondary schools, they have the necessary knowledge to either enter the workforce with additional vocational training appropriately adjusted according to qualifications; or to pursue further studies. Higher education programs are typically 3-6 years long, depending on the course or degree (Prime Minister, 2016). Further study at the postgraduate level is merited with graduate degrees of master and doctorate. Higher education in Vietnam only constitutes of postsecondary education leading to associates, bachelors, and higher degrees. ${ }^{1}$

Upon successfully universalizing primary education (Ministry of Planning and Investment, Department for Labor, Culture and Social Affairs, 2013), Vietnam aims to achieve universal lower-secondary education in the next 20 years. Demand for upper-secondary education will subsequently increase, which will put additional pressure on an already overburdened higher education system. According to The Ministry of Education and Training (2017b), in the academic year 2016-2017, Vietnam had 235 universities (65 non-public and 170 public institutions) enrolling over 1.7 million students, 1.5 million of those were fulltime. Despite the rapid rise in the number of tertiary education institutions, new enrollment continues to exceed available places. Most general assessments show that the top and middle schools only need to recruit once a year to meet the annual enrollment quotas (Pasteur Medical College, 2019). To provide mass education to students in Vietnam, the Government established the target that by 2020, private university students would account for 40 per cent of all enrollments (Resolution No. 14/2005/NQ-CP on substantial and comprehensive renewal of Vietnam's tertiary education in 2006-2020). Consequently, a more robust higher education sector has been formed that continuously calls for an increased role for private partnerships and provision. However, even though the Vietnamese Government has increasingly expected this sector to contribute more to the Vietnam's higher education system, it remains a peripheral sector in the current education landscape, whether in terms of student enrollment, or academic staff. The quality of private institutions, even accredited ones, continues to be a prime concern of society.

\section{Context of the study}

\subsection{Overview of the higher education}

The education system was, by law, centralized under the management of the Ministry of Education and Training (MOET), except for the two national universities administered by the Cabinet (Prime Minister, 2013b). One-third of higher education institutions answered directly to the MOET, while two-thirds came under the oversight of other ministries and provincial governments (Nguyen, Oliver, \& Priddy, 2009). Consequently, limited institutional autonomy was left for universities to manage and adjust themselves in response to the needs of the growing market economy. The adverse effects coming from the

\footnotetext{
${ }^{1}$ Higher education in Vietnam does not consist of vocational training.
} 
loose links between higher education providers, their students and employers, businesses, industries have stimulated the promulgation of several policies aiming to decentralize tertiary education and increase autonomy for institutions to improve their accountability for society since the 2000s. In 2014, Resolution No. 77/NQ-CP on piloting the renewal of higher education institutions was issued (The Government). Twenty-three pilot schools were approved to implement autonomy in three aspects: academic expertise, organizational personnel, and financial autonomy.

From July 1, 2019, institutional autonomy was extended to all higher education institutions, thanks to the revised Higher Education Law 2018 (National Assembly). The amendment of the Higher Education Law allowed universities to exercise full autonomy, from academia, finance to human resources, and expansion (National Assembly, 2018), which significantly reduces the time for administrative procedures by giving the highest authority to the School Council that has the full power to decide on the key personnel, the school's development strategy as well as major investment policies. Under the new regulations, nonuniversity members account for a minimum of 30 per cent of the total number of members of the School Board, including representatives of competent management agencies, scientists, entrepreneurs, alumni, representatives of employers (National Assembly, 2018). This composition will provide helpful insights to narrow the gap between theory and practice, school, and work as well as supervise the university's quality assurance conditions to meet the training requirements of each discipline. The new law also encourages mergers of higher education institutions (HEIs) as well as cooperation between universities and local industry groups to form major universities for multidisciplinary training (National Assembly, 2018). With that mechanism, institutions can support and collaborate, improving the competitiveness of Vietnamese universities with the world. Besides, the law allows the private university system to be developed equally, almost entirely with public schools, especially in terms of expertise. By renewing the financial and asset management mechanisms, tertiary institutions have the autonomy to determine tuition fees, commensurately with the quality of training and publicity. The State's budgets and resources will be allocated on the principle of competition, equality, and efficiency through investment spending, research and development, scholarship, and other funding forms.

\subsection{Non-public higher education}

The gradual achievements of Vietnam's education system are results of successive efforts to reform the whole country, starting when the policy of doi moi (renovation or transformation) was implemented in 1986 Sixth National Congress (Riedel \& Turley, 1999). After years in starvation and poverty caused by colonization, seemingly perpetual warfare, failed policies, and trade embargo ${ }^{2}$, Vietnam progressively re-engaged its economy to international trade and foreign investment. The "open door" strategy simultaneously brought about significant changes to every other aspect of its society. The rapid economic

2 imposed by the U.S. in 1975, lifted in 1994 by President Bill Clinton 
growth and greater flow of international ideas and interactions led to an increase in social demand for tertiary training to prepare the young generation with professional qualifications needed to be ready in the competitive workforce. Realizing the difficulty of separating higher education from economic progress and the adverse effects of limited education on social development, the government has accordingly adjusted its governing philosophy of higher education (Overland, 2006).

The development of non-public higher education after the reunification of Northern and Southern Vietnam in 1975 can be divided into two main periods:

- from 1975 to 2006: HEIs were organized in the forms of public, peoplefounded, and private.

- from 2006 up to the present: HEIs are categorized as public and non-public/ private

(for-profit and not-for-profit/non-profit)

\section{Period 1: from 1975 to 2006}

Applying the previous model of the North to consolidate the country's tertiary education system after reunification, the government of the newly founded Socialist Republic of Vietnam took over all responsibilities in higher education. Common to socialist central planning, the non-public sector was non-existent as all former private institutions in the South were merged and converted into public ones. New specialized universities, along with a large number of shortterm training colleges, were established under the oversight of ministerial and provincial authorities. Entirely dependent on state funds, higher education in Vietnam was severely affected by the economic crisis in the 1980s. Expenditure on public sector wages in real terms was drastically cut due to the high inflation and low levels of production. Salaries for educational personnel were reduced; investment in infrastructure and equipment for schools was consequently decimated. The implementation of doi moi from 1896 - 1992 blew in a breeze of new changes in education management and development orientation, among which was the recognition of other forms of ownership in higher education. The terminologies: people-found, private, and semi-public, for the first time, were mentioned in an authoritative document of the Government. In the same year, Decree No. 90/1993/ CP (The Government) was issued, stipulating that all Vietnamese citizens would have the right to pursue post-secondary education, which had led to a wave of massification and educational system reforms (Huong \& Fry, 2002).

As limited public capacities continued to urge the passing of a more adjustable training system, and the opening of new academic fields that were not present in the list of courses offered by the rigidly-managed public higher education, a new era for non-conventional higher education began. On a trial basis, in 1988, Thang Long University was authorized to operate as the first non-government institution. Beginning life as Thang Long Tertiary Education Center, it was placed under tremendous scrutiny and excessive caution during its foundation. 
At first, the center was only allowed to offer certificates for individual courses of study. Eventually, the Center was permitted to provide degrees by the MOET and became a fully-fledged people-founded university in the 1990s (Thang Long University, 2013).

People-founded universities referred to those that had been established by professional, social, or economic organizations, and funded by the organization's budget or investments from individuals. Due to the ideological discussions about the legitimacy of the private sector in the Vietnamese education system, Decision 196/TCCB was issued on January 21, 1994 (MOET, 1994). This "temporary regulation on the establishment of people-founded universities" aimed to avoid the connotations of 'private'. Accordingly, all nonpublic institutions that had been authorized to operate automatically became people-founded. This new structure for the system came as a result of the landmark Prime Ministerial Decree No. 90/ NDTTg (Prime Minister, 1993), at the Fourth Plenum of the Communist Party Central Committee (Seventh Term), that officially authorized and acknowledged non-public higher education institutions.

In contrast to Thang Long University, the later institutions enjoyed much greater leniency. Examples of overcrowding and mindless expansion in such early, underdeveloped stage were frequently reported in 1998, blaming irresponsible institutions for not guaranteeing the quality of their graduates. Criticism was also levelled at MOET for not examining the quality of the institutions seriously. Non-government institutions all far exceeded the enrolment quotas allocated to them by MOET. Although the number of students had increased rapidly during the 1990s across all institutions, nowhere was the increase more drastic and unchecked than in people-founded. The situation urged the government to suspend the approval of new requests to establish any non-public tertiary education providers until it investigated the problems.

On 11/12/1998, the first law governing the education system since 1945, The Law on Education, was enacted (National Assembly, 1998). Acceptance of nongovernmental ownership in higher education was reflected through classifications of institutions as public, semi-public, people-founded, and private institutions. Nonetheless, no further details were given regarding the status and role of private institutions in a state-dominated sector. Private education institutions are defined as institutions, in line with governmental regulations, founded and operated by private persons or investors to whom assets and savings of private higher education institutions belong. Unlike the public institutions, which get most of the resources from governmental investment, non-public HEIs are relying mainly on tuition. As the law 'forbids all actions commercializing educational activities' (Art. 17), but 'permits economic activities to support educational activities' (Art. 54) (National Assembly, 1998), non-public universities also depend on research and service activities carried out by their staff, or donations from organizations and, to a low extent, small subsidies from central or local governments. 
Based upon the stipulation of the Law on Education 1998, Prime Minister signed Decision 86/2000/QD-TTg (Prime Minister, 2000), which officially placed the people-founded universities in the higher education system. However, semipublic institutions, which were established based on once-public institutions due to the political nature of privatization in Vietnam, did not get any official acknowledgement yet, besides the temporary regulations on their organizations and operations. The definition of semi-public HEIs was not formulated either, except that these institutions have to operate on a cost-recovery basis, instead of relying on the public funds. The opening of higher education to the non-public stakeholders has highlighted an upward trending in the development of modern higher education in Vietnam, which is an increasing portion of the students willing to enrol in the new institutions on personal expenses.

In Decision No. 05/2005/NQ-CP, the notion of a semi-public educational institution was abolished (The Government, 2005). To concretize the guidelines on educational development in general and non-public institutions in particular, the Government issued several legal documents such as Decision No. 14/200/QD-TTg on January 17, 2005, detailing the organization and operation of private higher education providers (Prime Minister, 2005). On May 29, 2006, the Prime Minister signed Decision 122/QD-TTg, allowing 19 people-founded universities to switch into the form of private universities (Prime Minister, 2006). With the current regulations at this stage, higher education only exists in two types of public and non-public institutions. The first step in the movement toward the "marketization" of Vietnam's higher education sector took place when people-founded educational institutions were no longer established, and semi-public or people-founded educational institutions founded before January 1, 2006, were to transform to private private (Decree No. 75/2006/ND-CP detailing and guiding the implementation of a number of articles of The Education Law, 2006) ${ }^{3}$.

\section{Period 2: from 2006 up to the present}

Although the Higher Education Law 2012 advocated the development of notfor-profit institutions by stating that "taking advantage of education service to make profit is prohibited" (National Assembly, 2012), regulations like Decision 61/2009/QĐ- TTg (Prime Minister, 2009) and Decision 63/2011/QĐ- TTg (Prime Minister, 2011) viewed non-public university as a privately owned company with the General Meeting of shareholders as the highest decisionmaking body. Whereas the term "for-profit" was not in itself used, the organizational and operational regulations of non-public universities in Vietnam had been focused entirely on the type of for-profit private university. There had not been any rules regarding not-for-profit HEIs, let alone supervision of universities' operations to ensure that nonprofit regulations are followed. Under such circumstances of ambiguity, several legally-labelled non-profit private institutions are for-profit in practice.

\footnotetext{
${ }^{3}$ Non-public (including foreign-owned institutions) is the common term describing those educational institutions not categorized as public. From this point onwards, 'non-public' and 'private' are used interchangeably.
} 
As private HEIs applied the business model, shortcomings of quality of education started to emerge, which raised public concerns. Accordingly, the Vietnamese policymakers have made significant efforts to improve legal conditions for non-public HEIs to move from a purely business model to one that better serves students, faculty, and society. The Higher Education Law Law 2012 (National Assembly, 2012) and Decree No. 141/2013/ND- CP (The Government, 2013) were issued with detailed regulations and guidelines, which stipulated:

A not-for-profit private higher education institution is a higher education institution whose annual accumulated profit is a non-shared common asset, to reinvest in developing higher education establishments; shareholders or capitalcontributing members who do not enjoy income or enjoy annual income shall not exceed the interest rate of Government bonds. (Clause 7, Article 4)

Prime Ministerial Decision No.70/2014/QD-TTg went further to prescribe the governance structures of public, non-profit private, and for-profit private HEIs, as well as define "the control mechanism, the composition, and roles of the different bodies involved in internal university affairs" (Prime Minister, 2014) . This meant significant progress in education policy development when addressing not-for-profit institutions' fundamental and specific issues, fixing the conflicts between Higher Education Law and the clarifying documents, as well as creating a legal framework for their development.

Nevertheless, the issuance of these regulations has caused severe tension in terms of ownership and structure of power in some private institutions as the university leaders are also owners of the companies that have a business partnership with the institution. Educational experts believed that these instabilities had originated from ambiguity in policies and differences in values. As the first non-public universities were established or converted from semipublic and people-founded, the initial physical capital was usually limited. The main contribution was non-material such as intellectual property, connections, and prestige that had set the foundation for the universities to develop and accumulate assets during the operation. When transforming to private, collective ownership was turned into personal property, conflicts of interest among members are inevitable. In the complex nature of clashing ideologies without a stable legal framework, private universities continuously struggle to balance between public affairs of society and the private interests of individuals, social responsibility of the institution, and the motivation to seek profits of investors, between short-term and long-term benefits. Once a state monopoly, higher education is now witnessing vibrant privatization with the participation of business and professional investment. The dynamics of the private higher education market can be a good sign of the transition to professionalism in governance, and with it, quality improvement.

The drawbacks caused by inconsistent regulations on investment, ownership, and management for non-public higher education institutions have prompted the amendment and supplement of some articles of Higher Education Law 2018 
(National Assembly, 2018). One of the highlights in the revised law is the new regulations regarding not-for-profit private universities. Employing a progressive governance model, Vietnamese lawmakers are attempting to separate "ownership" from "governance", though the implementation of this entirely depends on the will and vision of the investors. Regulations on autonomy and accountability have been a step towards creating a relatively appropriate legal framework. It is too early to say how these modifications will work in practice, as there are many other factors involved in the operation of the universities. While giving more authority to the public universities and less intervention in private ones is a positive move, its implementation will be a great challenge without the assurance of equal rights.

\subsection{Achievements and challenges}

After 30 years, non-public higher education in Vietnam has made impressive strides in its expansion. In 1987, the country had 63 universities, none of which was non-public. Currently, there are 65 non-public universities, accounting for about 27 percent of the total number of universities in the country (MOET, 2017b). In the school year 2016-2017, there were 1,767,879 students, 243,975 of whom enrolled in private universities, accounting for 13.8 percent of the total tertiary education learners. In terms of teachers, there were 72,792 teachers in universities across the country, 20.8 percent of that work at private universities (MOET, 2017b). Since the school year 2013-2014, more than 150,000 students have graduated from non-public HEIs 4 . It is estimated that non-public tertiary education has annually contributed tens of thousands of new places for learners and jobs needed for the industrialization and modernization of the country.

Table 1. Higher education statistics

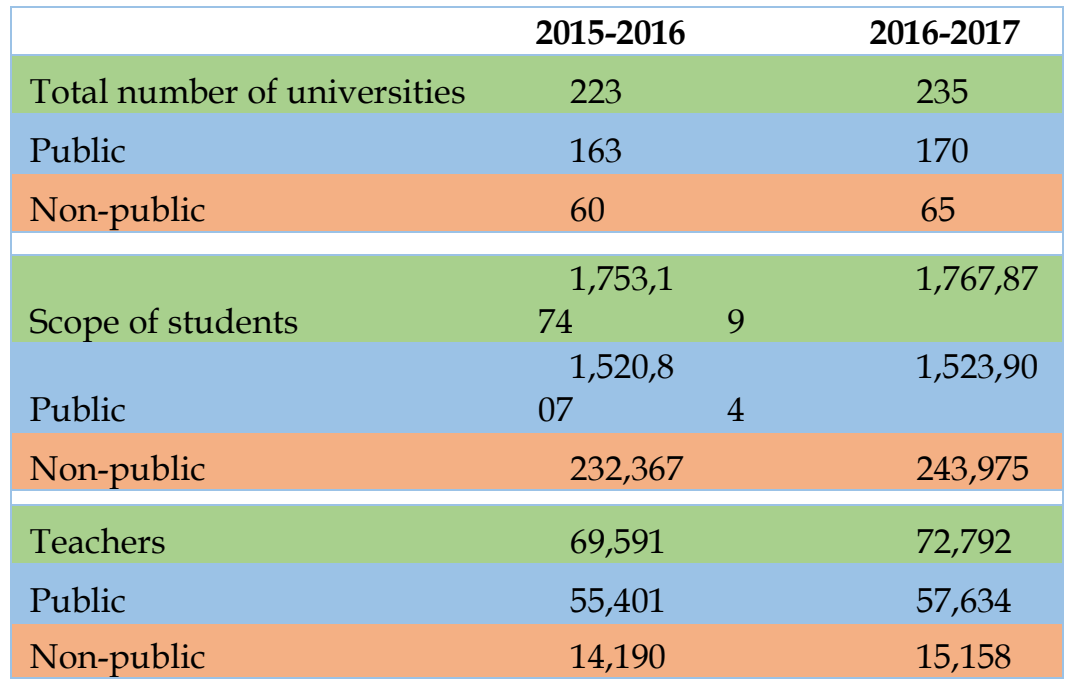

From the perspective of international integration, the Vietnamese private sector, albeit expanding, is not progressing under the trend of those developed higher education systems in the region, where participation of the private sector is increasingly prominent. Vietnam's situation is primarily due to tightened control

${ }^{4}$ Based on the calculation of the researcher 
from the government in response to concerns that the number of non-public universities was increasing exponentially. Requirements for forming a nonpublic university are becoming stricter and to some extent, impractical, far beyond such requirements for public HEIs. The maximum student size must be 15,000 , the minimum charter capital has to be 250 billion VND (about USD $\$ 11$ million), while the required land area for the head office cannot be less than 5 hectares, reaching an average of at least 25m2/student (Prime Minister, 2013a). Besides, Decision 64/2013/QD-TTg mandated that the Management Board must have one member who is a representative of the local authority where the university is based (Prime Minister, 2013b). Meanwhile, non-public universities are overseen by ministries and agencies at provincial and city levels (Prime Minister, 2013a). Thus, in the last ten years, 35 non-public universities were established while the number of public ones was 1.7 times higher ${ }^{5}$.

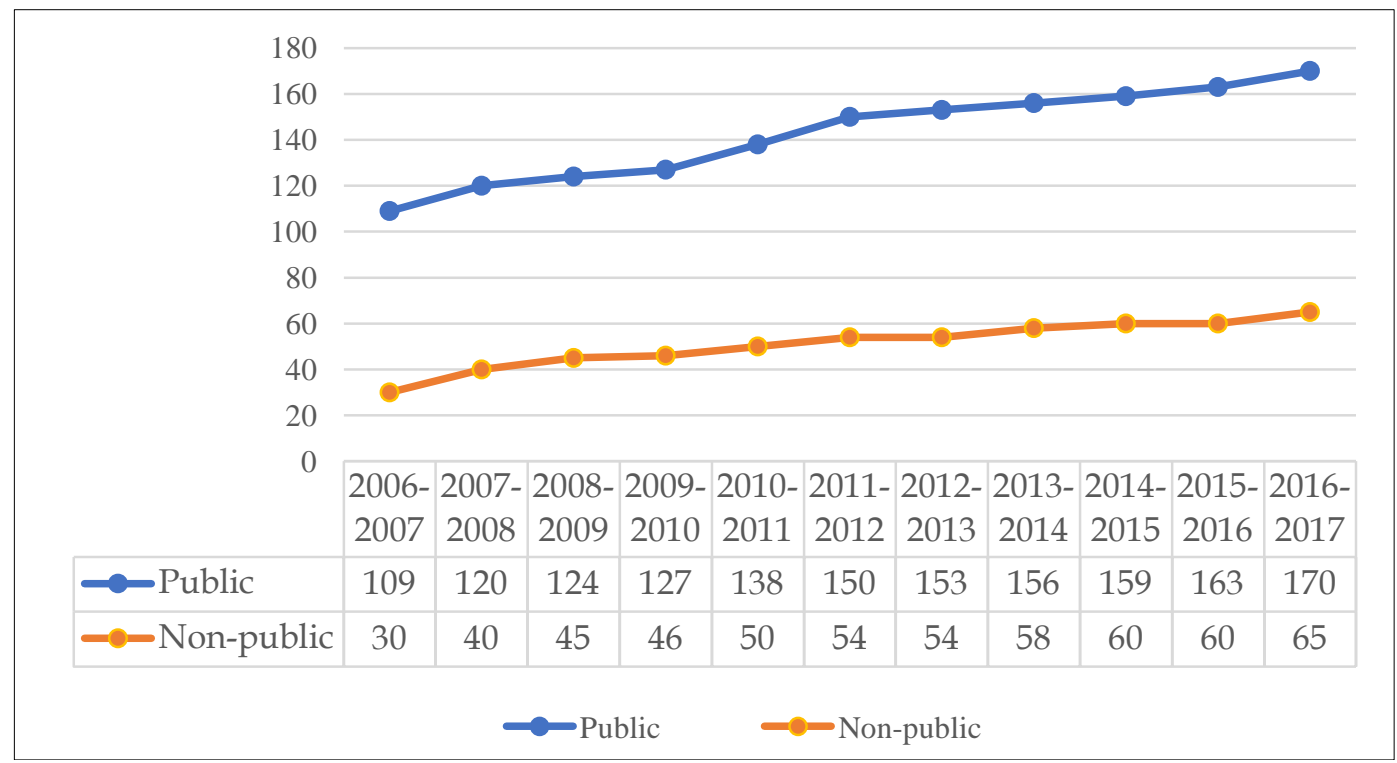

Figure 1. Changes in the number of universities

In the past 10 years, the lowest portion of students in non-public universities was in the school year 2013-20146 with 10.6 per cent, and the highest proportion was 13.8 per cent in 2016-2017 (MOET, 2017b), which was already an improvement compared to the previous school year, yet remained dramatically below expectation. Out of 418,991 new enrollments in the school year 2016-2017, 85 per cent belonged to the 170 public universities. Recording a 17.27 percent lower than the enrollment of the school year 2015-2016, the remaining 64,798 new students were admitted into those 65 private institutions, 5 of which are fully foreign-invested (MOET, 2017b).

\footnotetext{
${ }^{5}$ Based on the calculation of the researcher

${ }^{6}$ Due to the low number of graduation from high-school as well as the increased tuition fees for higher education
} 


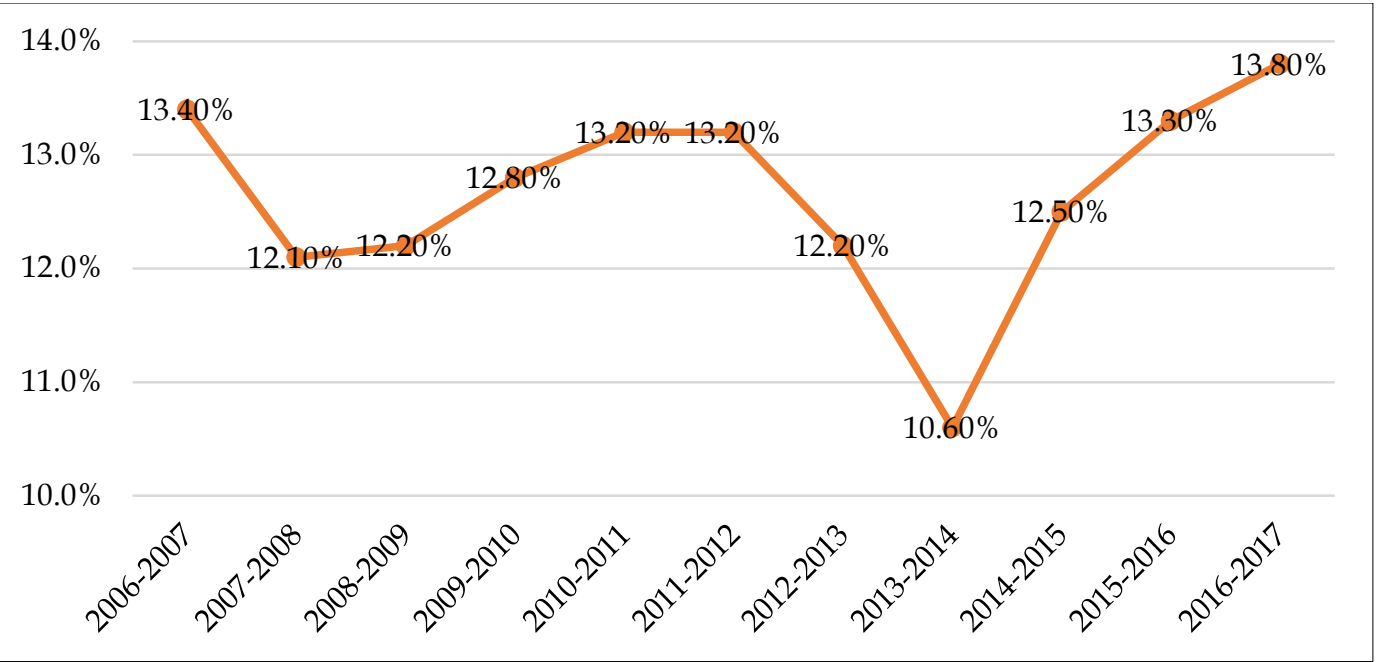

Figure 2. Proportion of Students in Non-public Universities

For years, higher education in Vietnam, especially the private sector, has faced several challenges. Not enrolling enough students, increasing rate of students dropping out after the first year, students being unemployed after graduation, or working in different fields rather than their degree majors, qualifications falling short of the international standards are to name a few. It is believed that the root of these problems is the fact that the quality of higher education does not meet the requirements of national development. The most obvious signs that the quality of higher education has not been as expected are the worrisome human capital flight coupling with the humble position of Vietnamese universities, and a small number of scientific works on prestigious regional and world assessment tables. Indeed, such beautiful words as "Harvard of Vietnam", "the largest training university in Vietnam" cannot conceal the concerning reality of higher education. The number of unemployed workers with a bachelor's degree at 4 per cent announced by the MOET recently does not seem to reflect the actual situation, especially when the phenomenon of students quitting universities is more and more prominent. Notably, the above survey only stopped at the leading and prestigious universities in Vietnam. When entrance requirement at some private universities and colleges is always at the lowest possible level to attract enough enrollment quotas, concerns and doubts about the quality of graduates from these institutions are inevitable.

Additionally, more and more foreign educational institutions are interested in and intend to open facilities, and branches in Vietnam after the initial success of some international universities such as International University in Vietnam, or RMIT. Although studying abroad is not a "magic wand", the value of foreign education is still attractive to many parents and students ${ }^{7}$. To create a legal corridor for foreign cooperation and investment, Decree 86/2018/ND-CP had been issued (The Government, 2018). The appearance of the foreign force in

\footnotetext{
${ }^{7}$ https:/ / www.tienphong.vn/xa-hoi/moi-nam-nguoi-viet-chi-3-den-4-ty-usd-di-du-hoc-1281310.tpo [Each year, Vietnamese people spend 3 to 4 billion USD to study abroad]
} 
Vietnam's higher education is an important premise for fierce competition in the coming time. With public universities, perennially favoured by the society, now receiving autonomy in enrollment quotas, challenges facing the private sector are much greater. The abolishment of minimal admission score 8 is considered as the right call to assist non-public institutions in student enrollment. The autonomy granted to universities in setting the admission score ${ }^{9}$ as well as choosing admission methods is believed to provide each university with the appropriate recruitment source, although concerns persist that admission of students with poor academic performance into higher education will impact education quality more negatively.

\section{Reflections and Suggestions}

From the above analysis, emerged three critical issues: admission, autonomy, and quality, each of which is a consequence intertwining with each other in an education system that develops at a much faster pace than the legal framework supporting it. Yet, these three issues are not only challenges but also opportunities for private universities when they are dealt with cautions. Autonomy can bring private universities more freedom in choosing the right strategy in their development path. With better strategic planning, admission can bring a more stable source of funding for the universities' operational activities, among which is an investment in quality improvement. Quality enhances the reputation and image of the private universities that, in turn, means easier recruitment of students. Nonetheless, private universities have a long way to go. A web of causes for the three issues will be discussed, based on which suggestions are given in the following sections.

\subsection{Quality}

Apprehensions about the quality of education in non-public institutions is everpresent. Many of Vietnam's private HEIs are considered as profit-driven demand-absorbing institutions, which provide the mass public with access to higher education through more inclusive admission criteria that most public universities cannot or are not willing to accommodate. Sequentially, public universities end up with the higher academically-achieving students, while private institutions remain "second chance" options for those not accepted elsewhere. As an additional route to obtain a degree, the private sector's contribution to meeting the growing demand for qualifications is impossible to negate. Nonetheless, private institutions are often perceived to be more expensive but less popular and preferred, compared to the top-tier public universities in terms of academic quality and rigour. Situations, where private degree education is viewed in a lesser light compared to the public university counterpart, have become alarmingly prevalent among the general public, including educators administrators, employers, and even private education students themselves. The negative views on private degree education are partly

\footnotetext{
8 "Floor points" were annually set by the MOET since 2004 as a measure to improve the quality of inputs.

${ }^{9}$ Except for pedagogy and health-related majors that require practice license.
} 
perpetuated by the stereotypes coming from society's mindsets that were passed down from the older generation about the merits of public university education.

Objectively, the lack of trust in the quality of private HEIs is not entirely unfounded, especially when the percentage of lecturers with bachelor's degrees still dominates (MOET, 2017b). In 2017, 51 private universities reported that they had never done any research project at the national level, 26 of which had never funded or invested in implementing institution-level projects, equivalent to almost no scientific research. 34 non-public HEIs had not even published any domestic articles (MOET, 2017a). The low quality of Vietnam's higher education in Vietnam, generally, is attributed to an eclectic mix of reasons, among which is the persistent lack of funds. Currently, state budget and tuition are the two primary sources of revenue for universities. The average state budget spent on education and training in the period of 2013 - 2017 was about 235,000 billion VND (accounting for about 20 per cent of the total state budget) ${ }^{10}$. This rate of investment for higher education in Vietnam is not only significantly low compared to many countries, but also exclusive of private education institutions. Additionally, the national level of investment in research and development is comparatively modest, at 1.52 per cent of the national research budget, accounting for only 0.41 per cent of the GDP (Ministry of Science and Technology, 2016). This constraint in the higher education system is primarily due to the limited investment capacity of the Vietnamese economy. In 2017, the level of GDP per capita for Vietnam was only US\$2,343, compared with a global average of US\$17,300 (World Bank, 2017). Moreover, tuition is the main source of private universities' income, accounting for over 61.17 per cent of the total revenues (MOET, 2017a). This is also the reason why many private universities tend to enrol more than the prescribed level, or massively increase tuition fees, as well as senselessly open new disciplines and forms of training. The significant increase in the number of students is inversely proportional to the quality of teaching and learning because the main expense for regular university activities such as salary payment for staff, electricity and water expenses, maintenance of facilities, taxes has already taken up more than 59 per cent. With less than half of the revenue left, up to 12 universities have to hire 100 per cent of their training facilities (MOET, 2017a). Notably, 5 out of these 12 institutions have been established for more than 20 years, while several other universities still do not have dormitories and suitable areas for physical education. The number of private universities currently operating on owned land is 24, accounting for just 36.9 per cent (MOET, 2017a). As a result, physical conditions at several nonpublic institutions are sadly lacking, particularly in terms of the paucity of wellequipped laboratories, library facilities, and computing infrastructure. Such a condition is hardly prerequisite for a quality educational environment, let alone for scientific research.

The increasing role of market regulation due to the modest national level of investment, along with the heterogeneous tertiary system as a result of

${ }^{10}$ https:// dantri.com.vn/giao-duc-khuyen-hoc/chi-ngan-sach-cho-giao-duc-la-248118-ty-dong-

20180930163940791.htm [In 2017: Budget spending on education is VND 248,118 billion] 
massification, raised the need to assure the quality of education. Institutional accreditation was thusly mandated with the expected aim of stimulating positive change toward improvements in the institutions. Nonetheless, several universities have been institutionally accredited irrespective of their inability to satisfy criteria that are fundamentally essential to the teaching and learning raises questions about the adequacies of the quality assurance system. The lax accreditation of universities has created legal loopholes for some units and organizations in this field to profit. An underground race took place among several private institutions through rampant introduction of new disciplines, development of joint degree, high-quality programs. Notably, many of these institutions introduced courses focusing on the fields that are "hot" in the labour market, despite the lack of expertise and experience required to conduct teaching and training for students. Since 2010, several unregistered offices, unstable facilities, etc. have been found and stopped by the MOET's inspection teams. Nonetheless, it seems to be just the tip of the "iceberg" of wrongdoings in university training compared to reality. Undeniably, thousands of graduates had graduated with a degree of poor value and quality before the inspection was conducted.

Ideally, the development of university rankings is necessary to improve transparency and enhance competition among universities. The issue of public ranking, stratification of universities and colleges is not a new policy, especially when the Government has issued documents and decrees revolving around this issue. The most recent was Decree 73/2015/ND-CP on stratification criteria, framework, and standards for ranking higher education establishments (The Government, 2015). Accordingly, the Decree stipulated quite sufficiently and strictly about the ranking of institutions in descending order depending on their qualities that were calculated based on the framework of each layer of highereducation systems. However, it can be seen that the higher education ranking framework of Decree 73/2015/ND-CP is too general to create a competitive force among universities that will motivate quality improvement. Additionally, the percentage of graduates who can find employment in the right training sector within 12 months is only classified in the quality of training and scientific research criteria, but not yet a major standard. This inadvertently becomes a gap in the ranking of universities, especially when the supervision and inspection of the implementation of these standards by the authorities are not close and careful enough to prevent universities from deliberately covering their performance. Another shortcoming from not considering the employment of students after graduation among the main training objectives is the frivolous achievement-driven path that many universities are following, where the number of international publications, the proportion of faculty members with Masters or Ph.D. is prioritized. Indeed, the number of international researches and reports, as well as the percentage of lecturers with master's and doctoral degrees in Vietnam has increased significantly in the past few years. It is encouraging yet, this is not necessarily a happy number when so far, no study has confirmed any improvement in the quality of private higher education. 
Quality education is a long-term commitment that requires an integrated system. To have good output, the input must be good. Thus, it is necessary to tighten the entrance process of enrollment based on changing the exam subjects and the examination block or method to suit the profession and training school. For example, an applicant who pursues studies in the IT industry should take Math, Physics, and English exams. Nonetheless, the input is the prerequisite that needs a good molding process, which starts from the quality of lecturers. At private universities that have cooperation with foreign institutions, academic staff can be sent abroad for pedagogical training or language courses. Among private universities, leading scientists and professors (including retirees) of Vietnam, as well as overseas, can help young lecturers to enhance their skills in both theoretical and practical aspects. Within the university, the staff needs to have more time and incentives to improve expert knowledge and training methodologies. The promotion of research activities can also be done through collaborative research opportunities by teaming up senior lecturers-researchers with junior staff. This approach not only solves the unbalanced load between teaching and researching but also enables junior teachers to strengthen individual and institutional research capacity. Moreover, investment in upgrading and renovating existing amenities or constructing new facilities like dorms, gyms along with equipping more modern machines and technology is indispensable to achieve the quality of education.

Meanwhile, inspection and evaluation of professional activities of universities, as well as their faculties need to be conducted regularly and more effectively. As these processes are being done internally and externally in most universities as required by the law, there should also be an independent organization with expertise in the assessment of accreditation of universities to ensure objectivity, honesty, and trust. The test results should be made public promptly. The evaluation also needs to be done on the criteria for recognition of students' degrees. Also, training must be linked to the reality of the general trend of the world, and more importantly, in line with the needs of the Vietnamese society. The measure for the output standard is the contribution that graduates can make to the businesses that employ them, to the community that they live in, and the society that nurtures them. The recognition of what students can do after their graduation is the best demonstration of quality training standards. To provide applicable knowledge, universities must be in close contact with the industries, companies, or businesses, at the same time, strengthen life skills for students by regularly organizing extracurricular activities, site visits, lab experiments, workshops. It is equally important to educate students on soft skills such as public speaking or critical thinking.

\subsection{Admission}

Despite the large quantity of labour force, the quality of Vietnam's human capital is relatively low. Based on the Global Human Capital Index assessed by World Economic Forum - WEF (Reports, 2017)), Vietnam ranked 64th out of 130 economies surveyed in 2017 in terms of human capital quality. In ASEAN, Vietnam stood in the bottom half, below the more developed members: 
Singapore, Malaysia, Thailand, the Philippines, and Brunei (WEF, 2017). The "skill deficiency" workforce is the consequential reality of a low quality higher education system. Besides, the number of unemployed university graduates increased significantly from 72,000 to 115,400 between 2013 and 2016, as reported by Institute of Labour Sciences and Social Affairs (2016) ${ }^{11}$. This status quo has prompted students to seek out the best education option to stay competitive in the graduate job market. When public and private universities do not put graduates on equal footing, the admission gate of non-public HEIs is inevitably narrower. The public system is increasingly bulging in the number and size of students. Meanwhile, private HEIs have increased in number, but the percentage of recruited students has hardly improved. In 2000, there were 17 non-public universities with a scale of 89,464 students, accounting for 12.2 per cent of the total number of tertiary learners. In comparison with 65 private universities and 267,530 students, accounting for 15.7 per cent of the total number of students, in 2018, the percentage of non-public university students increased by only 3.5 per cent in 18 years. As demonstrated, non-public universities have failed to implement the enrollment plan and will be unable to meet the expected 40 per cent of all admission by 2020. Many private universities and even some public ones with lower reputation continuously struggle to enroll students, as the source of recruitment from "floor points" becomes increasingly exhaustive, especially when several public universities set the benchmark on the entrance close to the "floor" of the Ministry. In majors without "floor points", private universities find themselves competing for students even more fiercely when the MOET has allowed universities to determine enrollment targets themselves (Promulgating Regulations on Procedures and Cycles of University, College and Professional Secondary School Accreditation, 2012). Consequently, the new enrollment of public universities in 2013 has reached a record of over 500,000 students, far exceeding the total enrollment targets of the whole system (both public and non-public) in the previous years. Thus, the abolishment of "floor points" is only effective under tightened enrollment criteria that will help each institution to choose the appropriate recruitment source, and avoid the exhaustion of recruitment resources.

Difficult enrollment for private universities is in part due to inaccessibility, as well as the prestige of the private sector in the Vietnamese way of thinking. Arguably, national policies have not been favorable toward the private sector either. Besides the regulations on the conditions and requirements to establish a private university, institution-based policies are also unpropitious. Most nonpublic universities have to fulfill the higher tax obligation, like other businesses. Students in private HEIs are not entitled to indirect incentives of the State such as scholarships, while have to pay other taxes, such as dormitory tax, food tax, parking tax on campus. Current Higher Education Law stipulated that: "The financial resources of the university education institutions include: State budget (if any)..." (National Assembly, 2018). As the MOET specifies this provision in the context of institutions having different governing bodies, it is thus difficult to have a common agreement on the budget allocated to each type of institution,

${ }^{11}$ Especially in the fields of business administration, banking, finance, and accounting. 
leading to inequality between universities and between learners at these institutions. The principle and mechanism of funding from the national budget, as well as the support of the State, have not created fairness among institutions and learners in different universities, a condition that is not ideal considering the only source of income for most private universities is the tuition fee. Inadequate enrollment of students in terms of quantity and quality negatively affects the financial situation in several private universities, which in turn impedes training and scientific research activities, the status quo which results in low admission in the first place. Thus, the policy should be attentive to the situations of the beneficiaries, regardless of whether they attend public or private institutions. The state should also exempt or postpone land rent and corporate income tax for non-public HEIs so that the budget of non-public universities can be used to invest in their facilities and develop human resources. The government can also take part in the investment in non-public HEIs by offering zero interest rates, as currently done in Hochiminh City. This interest rate is also low compared to funding for the public counterpart. Meanwhile, appropriate policies to gradually eliminate inequality between public and non-public institutions, between public and non-public students are prerequisites for the private sector to play a more prominent role in the higher education context. The state should also prohibit discrimination against private university graduates in labor recruitment.

Simultaneously, private universities need to carefully determine their recruiting criteria, because many of these institutions choose non-basic admission standard to recruit enough students, without regard to the quality later on. According to Circular 32/TT-BGDDT, the MOET should tighten the supervision of university enrollment targets based on training capacity and the survey results of the employment status of post-graduate students, as well as the mission assigned by the government (2015). Additional, a few proposals on restructuring and classifying the system of universities and colleges from 2020 to 2045 following the model of human resource development have been made. Specifically, the system of universities and colleges should include different types. Research and teaching universities will train up to doctoral degrees, regional universities possess the function of teaching up to master degrees and researching some fields, while 4-year bachelor-level universities implement different courses of training, and 2-year-diploma colleges. Particularly, entrance quotas for key public schools must be significantly reduced so more resources can be devoted to post-graduate training and scientific research activities while enabling the private sector to contribute more effectively. Besides, these HEIs need to be regulated on the quality of recruitment resources, as many countries have done, to maintain their brand stability. As research activities grow and new postgraduate programs are created, many institutions will eventually reform their category, while many others will improve their academic performance to remain in the same category. Moreover, universities offering the same majors should be combined, creating multi-disciplinary institutions. The reduction of the number of public universities also helps the government to manage and distribute resources more efficiently while the merge of research institutes and hospitals with universities supplements necessary research and teaching capacity. It is believed that some targets will be achieved, such as increasing population with 
university degrees, meeting management, technical and professional needs, improving the number of master's degree holders, and people with high professional training in the labour force, etc. The ultimate aim is the motivation to accomplish the highest possible quality standards through the coherence between objectives and resources.

\subsection{Autonomy}

Discussion about institutional autonomy has started since the establishment of the two national universities. In 2005, the top 4 public HEIs were chosen to pilot autonomy, but all stopped on the spot. It was not until 2014 that six public HEIs experienced autonomy and then twenty-three universities in 2017, although the level of autonomy is not true to the international meaning. The main reason originated from the state management agency itself (including the MOET and the provincial ministries). Despite their talks, these governing bodies of universities did not want to let go of their tight grip of controlling rights. A similar situation happened in the 1990s as the country entered the time of doi moi - renovation, when the centralized mechanism of management dominated about 10,000 state-owned enterprises, and no ministries wanted to relinquish control. The second reason came from the universities themselves. Like many of the board of directors of enterprises in the early 1990s, most principals wanted to continue the mechanism of subsidy and stability. The two most essential concerns often raised by educators and administrators pertains to equity and efficiency. Firstly, as autonomous institutions have the freedom to raise tuition fees, will access to a high-quality education no longer be available for students from low-income families, especially when enrolling in private universities means exclusion from being policy beneficiaries? Secondly, considering the current legal framework and knowledge of the higher education's sector, will the universities be able to operate effectively in achieving their missions without supervision and support from the State, the managing ministries, and the People's Committees of provinces? However, these two concerns are not without solutions as other countries have already resolved them.

The first concern highlights one of the most significant aspects of the concept of autonomy - financial autonomy. Indeed, concerns about equity are reasonable, yet several cases have demonstrated the ability of universities to adjust, among which was a good example set by Ho Chi Minh City University of Technology and Education - one of the first public HEIs to pilot autonomy. In the first year, the university had 45,000 students registered to apply. This number quickly dropped down to only 35,000 students after the publication of the tuition fees. However, with a good communication strategy, and high investment in quality improvement, the university's percentage of graduates with immediate employment increased significantly. Along with raising tuition fees, the university triples the scholarship fund from VND 12 billion to VND 36 billion/ year. Thus, with the same tuition fee, 60,000 candidates applied in the second year, As shown, initial recruitment difficulties from raising tuition fees do indeed occur. Additionally, autonomous HEIs may have to plan the reorganization of their faculties under expenditure cut while implementing a 
strategy to function more efficiently and improve the quality of training. It indeed will take time for the effort to autonomize higher education to gain momentum, yet financial autonomy does not mean self-financing for public universities. The government indeed does not allocate budget to public universities, but focus on job training according to the order model or invest in key industries that non-public HEIs cannot provide. Thus, the universities will eventually adjust themselves to stay competitive. Besides, autonomous universities have the right to earn more from social resources that are capable and desire to contribute more. At the same time, universities are encouraged to set up scholarship funds or a loan scheme to help students from economicallydisadvantaged families. Having operated without governmental financial support, private universities in Vietnam are more experienced in these regards. Thus this autonomy movement is more of progress toward equality, which is expected to foster a healthier competition between private and public universities. Furthermore, it is necessary to have a fair policy for private universities to access preferential loans as well as human resources from state investment (those who study abroad on the national budget).

About the second concern, autonomy is associated with accountability, as it is stipulated in Article 32 of the Revised Higher Education Law 2018 (National Assembly, 2018) and mandatory for universities to be institutionally accredited. In terms of asset management mechanism, universities are responsible for explaining and providing transparency of information to learners, society, competent management agencies, owners, and related parties in compliance with the law and regulations as well as under the commitments of the universities. Thus, autonomy does not mean HEIs, particularly private universities, will be left to struggle. Specifically, the new law established a legal corridor, based on which universities exercise autonomy, and state management agencies will supervise. Nonetheless, it is necessary to immediately eliminate the long-standing misconception of local government as the "governing body" of non-public universities. In a mechanism without heavy external interference, internal activities can be carried out more promptly and smoothly as decisions only need to go through the School Council and the Management Board, in which there must be one representative of the participating management agency. Universities can handle their issues more quickly as well as autonomously expand the training sectors or sign contracts with enterprises. As of now, private HEIs are, albeit autonomous, still required to do a lot of work to get permission, to be approved to open a training course, set up training facilities outside the main campus, or to cooperate with international establishments. Even for those accredited universities with strengths and resources in specific fields, the ministry decides when or whether they can develop or expand. This status quo not only goes against the concept of autonomy but also impedes the growth of private universities. Thus, the most crucial thing about autonomy is a more precise concept of autonomy and regulation of multiple levels of autonomy as a legal base for universities to operate without excessive bureaucracy.

Although the Revised University Education Law has given a lot of autonomy to HEIs, this new law will be seriously entangled with other legal provisions when 
enforced as the policy mechanisms do not keep up with one another nor the development pace. For instance, the new law does not stipulate the number of terms in principalship for an individual. However, the age regulation for the principal in the first term or retirement is still specified in other documents. Also, private universities are concerned about the lack of a synchronous legal system, namely one sentence in the guidelines of the MOET completely disabling autonomy of institutions that are regulated in higher-level texts. As an example, all titles in the university must be planned through several steps according to the regulation of the Central Organization Committee. The mobilization of resources for the universities' activities is also restrained by laws such as the Budget Law, the Law on Foreign Direct Investment, Law on Science and Technology, or the Law on Public Investment in the case of public HEIs. Notably, the Budget Law has not stipulated suitable tax policy to enable universities to mobilize social resources in the spirit of incentives for education. As universities are still heavily governed by taxes and service activities, it is difficult to attract funding, especially when donors investing the universities are not exempted from tax. Thus, it is necessary to immediately update and change not just the ways of thinking and operating but also the legal framework currently guiding the system. Ideally, the School Council must have the power to decide two issues. The first is the organization of the university's personnel apparatus (including the positions of principal, assistant principal, dean, head of the department). The second is the financial decision (e.g.: which expenditure level requires approval from the School Council or the Management Board, and which level the principal can decide). Additionally, more favorable tax incentives need to be in place as universities will now depend more on society's support. It is also vital to see the learner as a partner, not as a buyer of educational service since the revised Law does not address and considers them as an important component of the School Council in moving towards autonomy.

\section{Conclusion}

Up to now, educational socialization reflected in the Government's Resolution No. $05 / 2005 /$ NQ-CP and Resolution 29-NQ/TW of the XI is highly appraised. However, policies and implementation guidelines, in general, are still inadequate, stagnant, and even contradictory. The expectation of a synchronous, stable, and transparent policy system so far has not been met, as the concept of a private university itself has been changed three times (in Decision 196/TCCB of the MOET, Regulation 86/2000/QD-TTg of the Prime Minister and the Education Law 2005). Thus, it is vital to construct a legal framework that separates more clearly the two types of private universities, operating for-profit and nonprofit activities, especially those that are under the ownership of other financial organizations. Rather than seeing a not-for-profit private university as a special kind of private university, there must be clear guidelines for the separation of powers and functions between capital-contributing members (founders and investors), the board of directors (direction and supervisors) and administrators (management and administration). Meanwhile, it is necessary to maintain the stability of key organizations and personnel to keep the 
development momentum of each university, contributing to building a good autonomy model.

Importantly, more favorable conditions must be created, enabling private universities to actively and effectively implement autonomy, contributing to bringing the Party's Resolution into practice while contributing significantly to the fundamental and comprehensive innovation of education and training. As autonomy will allow private higher education institutions to develop flexibly, recruitment can better adapt to the needs and direction of the market. Through strategic planning, a stable venue is assured for the universities' operation, while more attention can be paid to enhance and achieve higher education quality. Quality enhancement, in turn, improves the reputation and position of the private universities, which equate to an easier enrollment of students. This is not only beneficial to the private sector but also solves the question of overload in the public counterpart. As public education and non-public education are like two wings of a bird - the national education system, both wings must be strong and balanced for Vietnamese education to fly high and reach far. In a decade or two, Vietnamese higher education will potentially have private universities ranked in the Top 500 elite universities of the world, becoming the pride of the country.

\section{References}

Huong, P. L., \& Fry, G. (2002). The Emergence of Private Higher Education in Vietnam: Challenges and Opportunities. Educational Research for Policy and Practice, 1(1-2), 127-141. doi:10.1023/ A:1021130320485

General Statistics Office. (2017). Socio-economic situation in 2017. Statistical publications.

Ministry of Education and Training. (1994, Jan 24). Decision No. 196/TCCB about temporary regulation on private universities. Vietnam.

Ministry of Education and Training. (2012). Promulgating Regulations on Procedures and Cycles of University, College and Professional Secondary School Accreditation. Circular No.62/2012/TT-BGDDT.

Ministry of Education and Training. (2015, Dec 16). Circular No. 32/2015/TT-BGDDT determination of enrollment targets of higher education institutions. Hanoi, Vietnam.

Ministry of Education and Training. (2017a). Conference on non-public higher education institutions. Ho Chi Minh: Ministry of Education and Training.

Ministry of Education and Training. (2017b, October 28). Higher education statistics for the school year 2016 - 2017. Retrieved from https:/ / moet.gov.vn/thongke/Pages/thong-ke.aspx

Ministry of Planning and Investment, Department for Labor, Culture and Social Affairs. (2013). Millennium Development Goals Full Report 2013. Hanoi: New Technology Printing Joint Stock Company.

Ministry of Science and Technology. (2016). Scientific research and technological development. National Assembly. (1998, Dec 2). Education Law No.11/1998/QH10. Hanoi, Vietnam.

National Assembly. (2012, Jun 18). University Law No. 08/2012/QH13. Hanoi, Vietnam.

National Assembly. (2018, Nov 19). The revised law amending and supplementing a number of articles of the university education law. Vietnam. 
Nguyen, K. D., Oliver, D. E., \& Priddy, L. E. (2009). Criteria for Accreditation in Vietnam's Higher Education: Focus on Input or Outcome? Quality in Higher Education, 15(2). 123-134. doi:10.1080/13538320902995766

Overland, M. A. (2006). Higher education lags behind the times in Vietnam. Chronicle of Higher Education, 52(4), 37.

Pasteur Medical College. (2019, Aug 21). Pasteur Medical College News. Các trường đại học lớn hầu hết đã tuyển đủ chỉ tiêu [Most major universities have recruited enough quotas]. Retrieved from https://caodangyduoc.com.vn/cac-truong-dai-hoc-lonhau-het-da-tuyen-du-chi-tieu

Prime Minister. (1993, Nov 24). Decree No. 90/ CP defining the structural framework of the national education system, educational awards and certificates for education and training. Vietnam.

Prime Minister. (2000, Jul 18). Decision No. 86/2000/QD-TTg about regulations on people-founded universities. Hanoi, Vietnam.

Prime Minister. (2005, Jan 17). Decision No. 14/2005/QD-TTg promulgating the regulation on organization and operation of private universities. Hanoi, Vietnam.

Prime Minister. (2006, May 29). Decision No. 122/2006/QD-TTg about converting people-founded university to private university. Hanoi, Vietnam.

Prime Minister. (2009, Apr 17). Decision No. 61/2009/QD-TTg issuing the regulation on organization and operation of private universities. Hanoi, Vietnam.

Prime Minister. (2011, Nov 10). Decision No. 63/2011/QD-TTg amending and supplementing a number of articles of the regulation on organization and operation of private universities. Hanoi, Vietnam.

Prime Minister. (2013, Nov 11). Decision 64/2013/QD-TTg promulgating conditions and procedures for establishing or allowing the establishment, allowing training activities, suspensing activities of training, merging, splitting, dissolution of universities and academies. Hanoi, Vietnam.

Prime Minister. (2013a, November 11). Decision on Issuing Conditions and Procedures for Establishing or Allowing the Establishment, Permission of training activities, Suspension of training activities, Merging, Division, Splitting, Dissolution of University and Academy. No. 64/2013 / QD-TTg.

Prime Minister. (2013b, November 17). Decree about National University. No. 186// NDCP.

Prime Minister. (2014, Dec 10). Decision No. 70/2014/QĐ-TTg promulgating the University Charter. Hanoi, Vietnam.

Prime Minister. (2016, October 18). Decision On Approval Of The Structure Framework Of The National National Education System. No. 1981/QD-TTg: Retrieved from: https://moet.gov.vn

Provincial Party Board. (1993, Jan 14). Resolution No. 04-NQ/HNTW about continuous innovation of education and training career. Hanoi, Vietnam.

Riedel, J., \& Turley, W. S. (1999). The politics and economics of transition to an open market economy in Vietnam. OECD Development Center.

Thang Long University. (2013, Aug 28). Thang Long University: General introduction about Thang Long University. Retrieved from http://www.thanglong.edu.vn/gioithieu/gioi-thieu-chung/780-gt-truong-dhtl

The Government. (1993, Nov 24). Decree No. 90-CP regulating the framework of the national education system, the document system, certificate of education and training. Hanoi, Vietnam. 
The Government. (2005, Apr 18). Resolution No. 05/2005/NQ-CP of April 18, 2005, on stepping up socialization of educational, healthcare, cultural, physical training and sport activities. Hanoi, Vietnam.

The Government. (2005, Nov 02). Resolution No. 14/2005/NQ-CP on substantial and comprehensive renewal of Vietnam's tertiary education in 2006-2020. Hanoi, Vietnam.

The Government. (2006, Aug 02). Decree No. 75/2006/ND-CP detailing and guiding the implementation of a number of articles of The Education Law. Hanoi, Vietnam.

The Government. (2013, Oct 24). Decree No. 141/2013/ND-CP guiding implementation Law on Higher Education. Hanoi, Vietnam.

The Government. (2014, Oct 24). Resolution No. 77/NQ-CP on pilot renovation of the operation mechanism of public tertiary education institutions during 2014-2017. Hanoi, Vietnam.

The Government. (2015, Sep 8). Decree No. 73/2015/ND-CP standards for stratification framework ranking higher educational institutions. Hanoi, Vietnam.

The Government. (2018, Jun 6). Decree No. 86/2018/ND-CP regulating foreign cooperation and investment in the field of education. Hanoi, Vietnam.

World Bank. (2017). Vietnam. Retrieved from https://data.worldbank.org/country/vietnam

World Economic Forum. (2017, September 13). The Global Human Capital Report 2017 [Reports]. Retrieved from https://www.weforum.org/reports/the-globalhuman-capital-report-2017 